\title{
Undergraduate Internships: \\ Conflicting Interests
}

\author{
David Greene (Corresponding Author) \\ The University of Northern Colorado \\ Gunter Hall 1250B \\ Campus Box 132 \\ Greeley, CO 80639 \\ E-mail: david.greene@unco.edu
}

Tel: 970-351-3131

Received: June 3, 2019

doi:10.5296/jet.v6i2.14880
Accepted: July 14, 2019 Published: July 30, 2019

URL: http://dx.doi.org/10.5296/jet.v6i2.14880

\begin{abstract}
Internships are becoming an important component in undergraduate programs across a wide range of disciplines. Escalating financial and scheduling conflicts have been found to force students to make difficult decisions regarding participation. This mixed methods case study was conducted in a human services undergraduate program that requires a 450-clock hour internship. It was hypothesized that a majority of students would recommend either a shorter internship, or elimination of the requirement entirely. The opposite was found. A significant majority $\left(X^{2}[2, \mathrm{n}=86]=47.53, p<.001\right)$ believed that the 450-clock hour internship was the appropriate length. This was consistent for females and non-traditional students, two at-risk groups for financial and scheduling conflicts. Qualitative responses suggested that students found successful ways to address the financial and scheduling concerns. This study provides support that students believe in the benefits of internship, even when facing financial and scheduling conflicts.
\end{abstract}

Keywords: Internship; Internship Length; Financial Conflict; Scheduling Conflicts

\section{Introduction}

The internship is an essential component in human services programs (Council for Standards in Human Services Education, [CSHSE], Standard 21, 2013), and increasingly required across a range of disciplines (Lierman, Townsley, Watermill, \& Rousseau, 2017). The National Association of Colleges and Employers (NACE, 2017) reported that over $60 \%$ of college graduates complete an internship. The University of Northern Colorado Human Services Program requires a 450-clock hour internship. The internship combines direct community 


\section{Macrothink Mnstitute"'}

engagement with academic instruction and involves students in meeting local community needs (Lee et al., 2018; Mehta \& Ahmed, 2018). The internship is a core element believed to be of great value to both the students and the community (CSHSE, 2013).

Recently there has been an increase in students voicing concerns about the length of the internship and the associated financial and scheduling conflicts. Literature suggests that those concerns have merit. Interns have been found to experience high levels of stress, anxiety, health-related problems, and interpersonal conflicts (Brough, Correa-Velez, Crane, Johnstone, \& Marston, 2015; Hemy, Boddy, Chee, \& Sauvage, 2016; Johnstone, Brough, Crane, Marston, $\&$ Correa-Velez, 2016). Financially, students report that internships interfere with their ability to maintain the necessary employment required to pay tuition and basic living expenses (Brough et al., 2015; Johnstone et al., 2016). Escalating tuition costs and decreased availability of financial assistance add to the financial strain (Mitchell \& Leachman, 2015; Newman, Dannenfelser, Clemmons, \& Webster, 2007). This is exacerbated by the preponderance of unpaid internships in the human services and other social and behavioral sciences (Brough et al., 2015; Crain, 2016; Gardner, 2010; Hemy et al., 2016; Johnstone et al., 2016; Lierman et al., 2017). It is additionally troubling that women are more likely to have unpaid internships than men (Crain, 2016; Gardener, 2010). These stressors are even more significant for nontraditional students who are dealing with higher levels of financial, employment, family and other responsibilities (Carnevale, Smith, Melton, \& Price, 2015; Hemy et al., 2016; Zosky, White, Unger, \& Mills, 2004).

While financial and scheduling struggles are increasing, there are well-documented benefits associated with internships. Students who complete internships have been found to have improved grade point averages, writing skills, problem solving skills, critical thinking skills, interpersonal skills, and perceptions of self-efficacy (Binder, Baguley, Crook, \& Miller, 2015; Madison, Grenci, \& Bockanic, 2017; Narayanan, Olk, \& Fukami, 2010). Career benefits include increased rates of employment, shorter amounts of time to secure employment, and higher starting salaries (Carnevale et al., 2015; Lierman et al., 2017). Benefits also include increased life skill development and a sense of civic responsibility (Astin \& Sax, 1998; O’Connor, Lynch, \& Owen, 2011).

Students face an increasingly difficult choice between the benefits of internship and potential financial and scheduling conflicts. This mixed methods case study examined a sample of students drawn from an undergraduate human services program regarding the internship experience. It was hypothesized that students would recommend either a shorter, more manageable internship, or eliminate the internship entirely. This was expected to the particularly true for at-risk non-traditional and female students.

\section{Method}

\subsection{Data Collection}

Data was collected using announcements distributed through the human services program email list serve. The announcement included a brief description of the study and that data was confidential, would only be used in aggregate form, and participation was voluntary. The inclusion criterion specified that participants must be a declared human services major. The 


\section{Macrothink}

Journal of Education and Training

ISSN 2330-9709

2019, Vol.6, No.2

announcement included an embedded, anonymous link to the survey. The survey was created in Qualtrics (2018), an on-line software survey tool. Two additional e-mail reminders were sent at approximately two-week intervals. No incentives for participation were offered. The study was approved by the University of Northern Colorado's Institutional Review Board.

\subsection{Survey Instrument}

The survey included the formal informed consent, followed by a series of both quantified and qualified questions. Students were asked if they believed the current program requirement for a 450-clock hour internship was about right, too much, or too little. (The 450-clock hours translated into 12 credit hours, based on a 37.5 clock hours per credit hour formula.). If students indicated that the internship was too much, they were asked to recommend a specific length, up to elimination of the internship. If students indicated that the internship was too little, they were asked to recommend a specific length, with no upper length limit. All students were asked to explain why they selected the option (about right, too much or too little) they selected. Students were also asked to identify their sex, traditional or non-traditional status, and if they were currently enrolled in internship. The survey was pilot tested with a random selection of 10 students to determine clarity, wording and comprehension.

\subsection{Sample}

The sample was comprised of 86 students drawn from the undergraduate human services program. The response rate was $37 \%$, an expected rate for a short, on-line survey, with no type of incentive (Guo, Kopec, Cibere, Li, \& Goldsmith, 2016). Sample demographics were 92.9\% $(\mathrm{n}=78)$ female, $7.1 \%(\mathrm{n}=6)$ male, 69.1\% $(\mathrm{n}=58)$ traditional, 30.9\% $(\mathrm{n}=26)$ non-tradition, and $23.3 \%(n=20)$ were currently enrolled in internship. The sample closely reflected the program which is $88 \%$ female, $70 \%$ traditional, and $18 \%$ enrolled in internship. The sample also reflected the class distribution of the program. The sample was $6.1 \%(n=5)$ freshmen, $13.4 \%$ $(\mathrm{n}=11)$ sophomores, $28.1 \%(\mathrm{n}=23)$ juniors, and $52.4 \%(\mathrm{n}=43)$ seniors. The program was $7.5 \%$ freshmen, $24 \%$ sophomores, $30 \%$ juniors, and $37.5 \%$ seniors.

\section{Results}

\subsection{Quantitative results}

A significant majority of students $(65.2 \%, \mathrm{n}=56)$ stated that the 450 -clock hour internship was about right. The second largest response group $(30.2 \%, \mathrm{n}=26)$ reported the internship was too much. The smallest response group $(4.7 \%, \mathrm{n}=4)$ reported the internship was too little. A chisquare test of goodness-of-fit determined the difference between the three response groups was statistically significant, $X^{2}(2, \mathrm{n}=86)=47.53, p<.001$ (Table 1$)$.

A chi-square test of goodness of fit was calculated to determine if there was a significant difference between males and females regarding length of internship. None was found, $X^{2}(2$, $\mathrm{n}=84)=.03, p>.05$. A chi-square test for independence was calculated to determine if there was a significant difference between traditional and non-traditional students. None was found, $X^{2}(2, n=82)=.49, p>.05$. A chi-square test of goodness of fit was calculated to determine if there was a difference for students currently enrolled in internship. None was found, $X^{2}(2, \mathrm{n}=$ 20) $=5.20, p>.05($ Table 1$)$. 


\section{Macrothink

The students who indicated that the internship was too much recommended a mean length of 300 -clock hours with a range of 225-375 clock hours. Students who indicated the length was too little recommended a mean length of 638-clock hours, with a range of 563-675 clock hours.

Table 1. Chi-Squared Results: Overall, Sex, Traditional / Non-Traditional Status, Internship Status

\begin{tabular}{lcccc}
\hline & About Right & Too Much & Too Little & Grand Total \\
\hline Overall & 56 & 26 & & 86 \\
Expected & 28.67 & 28.67 & 28.67 & 86 \\
& $\mathrm{df}=2$ & $p=0.01$ & $X^{2 \text { crit }}=5.99$ & $X^{2 \text { calc }}=47.53$
\end{tabular}

Observed

Females

Males

5124

Total

$\begin{array}{cc}3 & 78 \\ 0 & 6 \\ 3 & 84\end{array}$

Expected

Females

Males

Total

$$
\text { df }=2
$$

$\mathrm{p}=.89$

$\mathrm{X}^{2 \text { crit }}=5.99$

$$
\mathrm{X}^{2 \text { calc }}=.03
$$

Observed

Traditional

Non-Traditional

16
8
24

Total

Expected

$\begin{array}{lcccc}\text { Traditional } & 39.36 & 16.57 & 2.07 & 58 \\ \text { Non-Traditional } & 17.64 & 7.43 & 0.93 & 26 \\ \text { Total } & 57 & 24 & 3 & 84 \\ & \mathrm{df}=2 & \mathrm{p}=0.49 & \mathrm{X}^{2 \text { crit }}=5.99 & \mathrm{X}^{2 \text { calc }}=0.49 \\ & & 8 & & 20 \\ \text { Observed } & 10 & 6.67 & 6.67 & 20 \\ \text { In Internship } & 6.67 & \mathrm{p}=0.07 & \mathrm{X}^{2 \text { crit }}=5.99 & \mathrm{X}^{2 \text { calc }}=5.20 \\ & \mathrm{df}=2 & & \end{array}$

\subsection{Qualitative Results}

\subsubsection{About Right}

A significant majority of students indicated that the internship was about right, and 19 (34\%) provided a narrative rationale. Narratives categorized into three primary areas, career 
benefits, financial issues, and scheduling issues. Career benefits were noted by four students $(21 \%)$.

"The ability to work full-time at an agency and confirm my interest."

"Spending a lot of time should be sufficient for an informative, productive, and beneficial experience."

"Just enough to get you familiar with the type of field you want to get into."

"The timing of a 450-clock hour internship helps finding the right fit."

Financial benefits were noted by four students $(21 \%)$.

"The 450-clock hour internship allows me to keep my financial aid."

"It is an important funding issue."

"It allows me to maintain my full-time student status."

'If you do less than 12 credits [450-clock hours], you won't get financial aid."

The majority $(\mathrm{n}=11,58 \%)$ indicated scheduling issues.

"It is a good fit into a semester."

"It is similar to being a full-time student."

"It isn't too much, and it isn't too little."

"It's a nice semester length."

"It fits well into scheduling."

"450 hours is just enough to feel like a full-time experience but not too overwhelming."

"It is the same as if you took a full load of classes."

"I have taken more credits."

"It is almost like a full-time job."

"It's a full-time job for 15 weeks."

"The 12 credits [450-clock hours] best reflects the internship experience."

\subsubsection{Too Much}

The second largest response group indicated that the internship was too much, and 15 (58\%) provided a narrative rationale. Narratives split evenly into two areas, financial concerns and scheduling concerns. Eight students (53\%) noted financial difficulties.

"Working a full-time internship while also working a job to support yourself is impossible."

"Too much for students who work." 
"For many people with jobs, 450 hours is too much."

"Too difficult to work and do internship."

"The financial strain alone is enough to give people extreme anxiety."

"Paying tuition while working unpaid doesn't seem fair."

"450 hours is too much while paying for rent and other living expenses."

"It is like working a second, full-time job."

The challenges of scheduling were noted by seven students (47\%).

"Too much with work and other responsibilities."

"The availability of an internship after my work hours was almost non-existent."

"Very difficult for someone who is a student athlete and works like me."

"Not reasonable along with my other responsibilities."

"Very difficult to balance with raising my three kids."

"Since we already do a lot of volunteering in the program, 450 hours seems unnecessary."

"Many of us are already working in the field."

\subsubsection{Too Little}

The two students who provided a narrative rationale suggested career benefits.

"I really want to get invested in the work and I'll be able to do more projects."

"I think this gives more exposure which allows more opportunity to explore the field."

\section{Discussion}

An increasing number of students are being asked to complete internships as part of their undergraduate education and training (Lierman et al., 2017; NACE, 2017). While the benefits of internship are well established (Astin \& Sax, 1998; Binder et al., 2015; Carnevale et al., 2015; Lierman et al., 2017; Madison et al., 2017; Narayanan et al., 2010; O'Connor et al., 2011), associated financial and scheduling conflicts are noted (Brough et al., 2015; Hemy et al., 2016; Johnstone et al., 2016; Mitchell \& Leachman, 2015; Newman et al., 2007). The University of Northern Colorado undergraduate human services program requires completion of a 450-clock hour internship. Based on an increased awareness of student concerns regarding internship, it was hypothesized that a majority of students would recommend either a shorter internship, or elimination of the requirement entirely. The opposite was found. A significant majority believed that the 450-clock hour internship was the appropriate length. This was consistent for females, a group that are at much greater risk of serving in unpaid internships (Crain, 2016; Gardener, 2010). This was believed to be due to the preponderance of internships for both females and males in the human services being unpaid (Brough et al., 2015; Crain, 2016; 


\section{Mll Macrothink}

Journal of Education and Training

ISSN 2330-9709

2019, Vol.6, No.2

Gardner, 2010; Hemy et al., 2016; Johnstone et al., 2016; Lierman et al., 2017), thus equalizing the financial burden for females.

The most surprising finding was that non-traditional students supported the 450-clock hour internship. Non-traditional students are the most likely to experience high levels of financial, employment, and family stress during internships (Carnevale et al., 2015; Hemy et al., 2016; Zosky et al., 2004). Yet non-traditional students reported that the length was appropriate, in slightly higher numbers than traditional students (69.2\% versus $67.3 \%)$. This suggests that nontraditional students might be more cognizant of the benefits of real-world experience.

The qualitative responses provided valuable insights. Students who indicated that the length was about right were very pragmatic about dealing with financial and scheduling issues. Three themes emerged. First, they recognized the length of the internship allowed for continuation of full-time student status and their ability to qualify for financial aid (e.g. "The 450-clock hour internship allows me to keep my financial aid."). Second, they addressed the issue of not being paid for internships. They recognized that while most internships are not paid, neither would they be paid to attend an equivalent load of 12 credit hours of traditional classes (e.g. "It is the same as if you took a full load of classes"). Third, they recognized and acknowledged the career benefits of internship (e.g. "Spending a lot of time should be sufficient for an informative, productive, and beneficial experience."). The few respondents who suggested a longer internship also focused on the career benefits ("I really want to get invested in the work and I'll be able to do more projects."). Both the students supporting the 450-clock hour internship $(65.2 \%)$, and those suggesting a longer internship (4.2\%), successfully addressed the main financial and scheduling conflicts (Brough et al., 2015; Carnevale et al., 2015; Hemy et al., 2016; Johnstone et al., 2016; Mitchell \& Leachman, 2015; Newman et al., 2007; Zosky et al., 2004).

Respondents who indicated that the internship was too long also focused directly on the associated financial and scheduling difficulties (Brough et al., 2015; Carnevale et al., 2015; Hemy et al., 2016; Johnstone et al., 2016; Mitchell \& Leachman, 2015; Newman et al., 2007; Zosky et al., 2004). Narrative responses suggested that the 450-hour internship was untenable from both financial ("The financial strain alone is enough to give people extreme anxiety") and scheduling perspectives ("Not reasonable along with my other responsibilities"). Still, no respondent recommended an internship less than 225 clock hours. This suggested that despite financial and scheduling concerns, there was still a belief in the benefits of internship. The solution was to shorten, but not eliminate the internship.

\subsection{Implications}

This study found that a significant majority of respondents found a 450-clock hour internship to be an appropriate length. This implies that despite the potential financial and scheduling difficulties associated with internships (Brough et al., 2015; Carnevale et al., 2015; Hemy et al., 2016; Johnstone et al., 2016; Mitchell \& Leachman, 2015; Newman et al., 2007; Zosky et al., 2004), the majority of students still believed in the benefits of internship (Astin \& Sax, 1998; Binder et al., 2015; Carnevale et al., 2015; Lierman et al., 2017; Madison et al., 2017; Narayanan et al., 2010; O’Connor et al., 2011). Even the students who indicated the internship 


\section{Mll Macrothink}

Journal of Education and Training

ISSN 2330-9709

2019, Vol.6, No.2

was too long suggested it should be between 225 and 375 hours (mean $=300$ ). No one suggested the internship be eliminated or even voluntary. Narrative comments suggested that students who could resolve the anticipated financial and scheduling conflicts, supported the length. Those who could not, believed shortening the internship would suffice. This distinction implies that addressing internship related financial and scheduling conflicts may decrease student stress and increase support for internships.

Student support is important for the design of higher education programs. Evidence suggests that engaging students in program requirements, activities, and learning conditions can be beneficial to successful program outcomes (Coates \& McCormick, 2014). Successful program outcomes are linked to recruitment and retention, essential considerations in higher education today (Bejou \& Bejou, 2012).

\subsection{Limitations and Future Directions}

As with any study involving volunteers, the ability to secure a representative sample is challenging. This study was no exception. Given students' personal involvement in the program, the response rate seemed low (37\%). Reasons for low response rates are multifaceted. It is impossible to know how many non-responses were simply because of email overload, personal time restraints, lack of personal incentives to complete, and survey fatigue. These likely contributed to non-response.

All participants were self-selected and from one program. It is suspected that people who were particularly interested in the design of the internship may have been more willing to participate. Future research should attempt to control for these factors. More rigorous outreach and the use of incentives are suggested. Sampling should include multiple, randomly selected programs in a range of disciplines. This will allow for more representative data and the ability to generalize. Sampling should also include students who have completed the internship and transitioned into the field.

Self-reported data was used in this study and reflects associated weaknesses. Students may have answered in a way they thought the researcher desired or may have simply misunderstood or misinterpreted the questions. The use of a Qualtrics (2018) survey provided anonymity, and questions were pilot tested for clarity in an effort to minimize these limitations.

\section{Conclusion}

The internship is an integral component in not only human services programs but a growing array of other disciplines (CSHSE, 2013; Lierman et al., 2017; NACE, 2017). The benefits of internship are well recognized (Astin \& Sax, 1998; Binder et al., 2015; Carnevale et al., 2015; Lierman et al., 2017; Madison et al., 2017; Narayanan et al., 2010; O'Connor et al., 2011). Yet the benefits must be considered in relationship to the financial and scheduling concerns experienced by students (Brough et al., 2015; Carnevale et al., 2015; Hemy et al., 2016; Johnstone et al., 2016; Mitchell \& Leachman, 2015; Newman et al., 2007; Zosky et al., 2004). This mixed methods case study examined the beliefs of a sample of undergraduate students enrolled in a human services program. Given growing concerns about the financial and scheduling difficulties, it was hypothesized that a majority of students would suggest a 


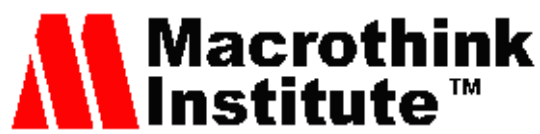

reduction or elimination of internship hours. This was particularly anticipated for females and non-traditional students who experience greater financial and scheduling conflicts (Carnevale et al., 2015; Crain, 2016; Gardner, 2010; Hemy et al., 2016; Zosky et al., 2004). The opposite was found. A significant majority of students found the 450-clock hour internship requirement to be an appropriate length. This held true across sex and traditional / non-traditional status. This study supported that students believe in the benefits of internship, even when facing financial and scheduling conflicts.

\section{Conflict of Interest}

There are no conflicts of interest relevant to this manuscript for the author.

\section{Funding}

The author received no financial support for the research, authorship, and/or publication of this article.

\section{References}

Astin, A. W., \& Sax, L. J. (1998). How undergraduates are affected by service participation. Journal of College Student Development, 39, 251-263.

Bejou, D. \& Bejou, A. (2012). Shared governance and punctuated equilibrium in higher education: The case for student recruitment, retention, and graduation. Journal of Relationship Marketing, 1, 248-258.

Binder, J., Baguley, T., Crook, C., \& Miller, F. (2015). The academic value of internships: Benefits across disciplines and student backgrounds. Contemporary Educational Psychology, 4173-82. doi:10.1016/j.cedpsych.2014.12.001

Brough, M., Correa-Velez, I., Crane, P., Johnstone, E., \& Marston, G. (2015). Balancing the books: An assessment of financial stress associated with social work and human service student placements. Retrieved from http://eprints.qut.edu.au/82024/3/82024.pdf

Carnevale, A. P., Smith, N., Melton, M., \& Price, E. W. (2015). Learning while earning: The new normal. Center on Education and the Workforce, Georgetown University. Retrieved from https://cew.georgetown.edu/wp-content/uploads/Working-Learners-Report.pdf

Coates H., \& McCormick A. (2014). Introduction: Student engagement-a window into undergraduate education. In H. Coates \& A. McCormick (Eds.), Engaging university students. Singapore: Springer

Council for Standards in Human Services Education. (2013). National standards baccalaureate degree in human services, revised. Retrieved from http://www.cshse.org/pdfs/Standards-Baccalaureate.pdf.

Crain, A. (2016). Understanding the impact of unpaid internships on college student career development and employment outcomes. NACE Foundation Report. Retrieved from https://careersservices.nmsu.edu/files/2017/03/the-impact-of-unpaid-internships-oncareer-development.pdf 


\section{Macrothink

Gardner, P. (2010). The debate over unpaid college internships. Retrieved from http://www.ceri.msu.edu/wp-content/uploads/2010/01/intern-Bridge-Unpaid-CollegeInternship-Report-FINAL.pdf

Guo, Y., Kopec, J. A., Cibere, J., Li, L. C., \& Goldsmith, C. H. (2016). Population survey features and response rates: A randomized experiment. American Journal of Public Health, 106, 1422-1426. doi:10.2105/AJPH.2016.303198

Hemy, M., Boddy, J., Chee, P., \& Sauvage, D. (2016). Social work students “juggling' field placement. Social Work Education, 35, 215-228. Retrieved from http://www.tandfonline.com/doi/full/10.1080/02615479.2015.1125878?src=recsys

Johnstone, F., Brough, M., Crane, P., Marston, G., \& Correa-Velez, I. (2016). Field placement and the impact of financial stress on social work and human service students. Australian Social Work, 69, 481-494.

Lee, J. J., Townend, P. A., Boersma, J. M., Tippett,, T. P., Clements, C. M., \& Hicks, R. A. (2018). Promoting community engagement: A campus-wide approach to applied learning. Partnerships: A Journal of Service-Learning and Civic Engagement, 9, 31-43.

Lierman, L., Townsley, E., Watermill, J., \& Rousseau, D. (2017). Internships: Career outcomes for the liberal arts. NACE Journal, 77, 41-47.

Madison, R. L., Grenci, R. T., \& Bockanic, W. N. (2017). The value of student internships and faculty residencies. Management Accounting Quarterly, 18, 22-31.

Mehta, S. S., \& Ahmed, I. (2018). Planning academic community engagement courses. In H. $\mathrm{K}$. Evans (ed.), Community engagement best practices across the disciplines: Applying course content to community needs. Linham, MD: Rowman \& Littlefield.

Mitchell, M., \& Leachman, M. (2015). Years of cuts threaten to put college out of reach for more students. Center on Budget and Policy Priorities. Retrieved from http://www.tucsonsentinel.com/files/entryimages/cbpp_report.pdf

NACE. (2017). The class of 2017 student survey report. National Association of Colleges and Employers. Bethlehem, PA.

Narayanan V. K., Olk P. M., \& Fukami C. V. (2010). Determinants of internship effectiveness: An exploratory model. Academy of Management Learning \& Education, 9, 61-80

Newman, B. S., Dannenfelser, P. L., Clemmons, V., \& Webster, S. (2007). Working to learn: Internships for today's social work students. Journal of Social Work Education, 43, 513 528.

O’Connor, K. M., Lynch, K., \& Owen, D. (2011). Student-community engagement and the development of graduate attributes. Education and Training, 53, 100-115.

Qualtrics. (2018). Qualtrics: Qualtrics experience management platform. Retrieved from https://www.qualtrics.com 


\section{Macrothink

Zosky, D. L., White, K. B., Unger, J., \& Mills, S. (2004). Non-traditional students in social work: Diversity within. The Journal of Baccalaureate Social Work, 10, 28-45.

\section{Copyright Disclaimer}

Copyright reserved by the author(s).

This article is an open-access article distributed under the terms and conditions of the Creative Commons Attribution license (http://creativecommons.org/licenses/by/3.0/). 